\title{
LA REPRESENTACIÓN DE LA MUJER PERIODISTA EN EL CINE ESPAÑOL (1896-2010): \\ ESTEREOTIPO, ÉTICA Y ESTÉTICA
}

\author{
Lucía Tello Díaz \\ lucia@todosalcine.com \\ Universidad Complutense de Madrid
}

Recibido: 28-02-2012

Aceptado: 16-03-2012

\section{Resumen}

La mujer en el cine español ha sido retratada desde sus comienzos de manera reduccionista, enclavada en un doble estereotipo marcado por su actitud respecto a la sexualidad. De este modo, encontramos mujeres dóciles y sumisas, o bien femme fatales que acaban pagando su desenfreno y traición al arquetipo tradicional. En el caso de las periodistas, el giro cobra mayor relevancia si cabe, ya que las mujeres informadoras asumen los roles masculinos, sin dejar de padecer los daños propios de la condición de la mujer en nuestro cine. Descubrir cuáles son las claves de ese estereotipo y ponerlo en relación con la imagen global de la mujer en el cine, será el objetivo de la presente investigación.

Palabras clave: mujer, cine español, estereotipo, ética, estética, imagen.

\begin{abstract}
Since the beginning of the Spanish cinematographic industry, women have been portrayed with a recurrent reductionism marked by their attitude about their sexual life. Thus, in Spanish films we find docile and submissive women, or femme fatales who end up paying the price for their dissipated lives. In women journalists' case, this image takes a new turn, as far as female reporters assume a masculine role. Despite this attribution, they keep on suffering the common damages found in fiction women. To discover the key points of this stereotype and relating them to the global female image in movies is the goal we aim to achieve in the current research.
\end{abstract}

Keywords: Women, Spanish films, stereotype, ethics, esthetics, image. 


\section{Introducción. La mujer en el cine: Cuestiones generales del estereotipo mediático} Es muy difícil que en un país se consiga cambiar las relaciones entre mujeres y
hombres, si eso no ocurre en el cine ni en la televisión (Roldán, 2009:24).

Inés París, presidenta de CIMA.

Toda imagen es una reducción artificial de una realidad rica y matizada. Esto es así porque resultaría impensable condensar toda la amalgama de posibilidades que se ofrecen en la naturaleza, es decir, en la realidad tangible, en una simple reproducción. Si toda recreación del entorno implica necesariamente un recorte de visos y matices, el resultado siempre será una trascripción sencilla, y en aspectos huera, de lo que es la vida real tal como la conocemos. Sin embargo, una reproducción no sólo es la versión simplificada del universo circundante, ya que "ninguna imagen es simplemente un calco o una reproducción de lo real. Todas son una representación, y las representaciones, por el simple hecho de serlo, modifican lo representado" (VV.AA., 2003:149). De ello se deriva que la mayor parte de las conceptualizaciones que se generalizan a través de los medios sean, no ya meramente reducidas, sino erradas. Estos conceptos equívocos, que simplifican la realidad para deglutirla sin necesidad de reflexión mediante, es lo que se conoce comúnmente por estereotipo.

Aunque los estereotipos nacen consustanciales a la naturaleza humana, por nuestra necesidad intrínseca de reducir la complejidad para entenderla, debemos al periodista Walter Lippman $^{1}$ y a su obra Opinión pública (1922), su actual aplicación a la sociedad de masas, afirmando que la mayor parte de los valores que atribuimos a determinadas realidades y grupos humanos, son adquiridos en el seno de la familia, la cultura, el arte y los medios de comunicación. Y es precisamente esa realidad reflejada en los medios la que nos atañe para hablar en términos de retrato de la mujer en el cinema. Ya hemos mencionado en numerosas ocasiones que la imagen proyectada por el cine influye en gran medida en la percepción que el público tiene de ese personaje, no como sujeto aislado, sino como entidad representante de todo un conjunto. De ahí que hablemos del poder creador de estereotipos del cinema, y de ahí también, que nos concierna analizar la imagen que de la mujer se aporta, para entender en qué difiere o qué la relaciona con la figura que de la mujer periodista se cincela en nuestra industria. En este sentido los media en general (y el cine en particular), en su papel de agentes de socialización "conforman parte de nuestra percepción de la realidad, proponen pautas de comportamiento social" (VV.AA., 2003:17), y como tales herramientas de influjo social, se infiere que "deberían instaurar directrices profesionales y mecanismos de autorregulación para fomentar la presentación de imágenes no estereotipadas de mujeres y hombres" (VV.AA., 2003:17).

Y es que la representación estereotipada de la mujer en los media es uno de los recursos (con) más impertinente frecuencia dentro de nuestra sociedad mediática. Sea en anuncios

\footnotetext{
1 Sin desdeñar, por supuesto la obra de Theodor La personalidad autoritaria (1969), trabajo imprescindible para entender los estereotipos a partir de la década de los años cincuenta.
} 
impresos, películas, programas televisivos e incluso cuñas publicitarias, las féminas, y concretamente su cuerpo instrumentalizado, han servido de vehículo para promocionar, suscitar o vender los más variados valores, conductas y productos. Según Bourdieu, al emplearse el cuerpo femenino en este mercantilismo, la perspectiva desde la que es mirado, eminentemente masculina, produce de inmediato una subordinación femenina al hombre:

“[...] el cuerpo femenino, ofrecido y rechazado al mismo tiempo, manifiesta disponibilidad simbólica a la que está obligada la mujer, como han demostrado muchos trabajos feministas, como combinación de un poder de atracción y de seducción conocido y reconocido por todos, hombres y mujeres, precisamente para agradar a los hombres de los que depende o se vincula y de una obligación de rechazo selectivo que añade, al efecto de la ostentación consumista, el precio de la exclusividad" (VV.AA, 2003:27).

No en vano, como el hombre es "el portador de la mirada y al ser la mujer la cosa mirada, la identidad femenina depende de la mirada evaluadora masculina" (Aguilar Carrasco, 2006). Además del patente androcentrismo manifestado en los recursos narrativos típicamente cinematográficos como el rol protagónico, que convierte a la mujer en un personaje vicario a expensas de los movimientos activos y voluntarios masculinos, la propia naturaleza del cinema y sus implícitos recursos de empatía y proyección de idearios e influencias, arrastran consigo la creación de estereotipos en serie, con todo lo que ello implica. La personalidad del personaje, sus circunstancias y el modo comportamental del que hace alarde, serán elementos decisorios que determinen la imagen estereotipada que se atribuye a la mujer:

"Cuando de la imagen se trata, lo primero que hay que distinguir desde la perspectiva de género es la figura humana y el escenario en el que se la sitúa. Esto es importante puesto que este escenario dará idea de la medida social de la persona: su papel personal y profesional, su categoría, y el valor ideológico y simbólico que se le concede" (VV.AA, 2003:17).

Generalmente, las características atribuidas a los personajes femeninos incurren en la redundancia de roles que pecan de pasividad y determinismo, expresando que las mujeres deben atender a un destino manifiesto con resignación y conformismo. Por otro lado, "siempre aparecen los hombres como los activos, los que toman decisiones, sin embargo los personajes femeninos son pasivos, dependen del hombre protagonista" (Roldán, 2009: 24). En este sentido, resulta estremecedor que en los relatos de ficción cinematográfica no se atienda a la evolución real de la propia mujer, sino que se mantengan programática y concluyentemente, unos cánones comportamentales rígidos y estereotipados que responden a una ficción creada en torno a la mujer, y no una representación fidedigna y acomodada a la realidad. Configurados como interlocutores subordinados a los designios masculinos del protagonista (personaje con el que, por otro lado, nos sentimos plenamente identificados por establecer el punto de vista desde el que la narración es descrita), las figuras femeninas pululan como atributos añadidos al hombre, sin que su acción pueda contravenir o determinar el desarrollo de la ficción cinematográfica -si acaso, actuarán como agentes complicadores-: 


\begin{abstract}
"Al negársenos el protagonismo del relato social, se nos niega el espacio y la mirada. Se ejerce contra nosotras una terrible violencia simbólica. Así sometidas se nos unce al carro del sujeto que tiene la llave del significado y del sentido. Fuera de su senda sólo hay tinieblas. Esta violencia es la madre de todas las otras, la que las espolea, las argumenta, las prepara y las justifica" (Aguilar, 2002:78).
\end{abstract}

Así las cosas, y a resultas del denominado "dominio patriarcal" que ha copado, entre otros espacios, la realización cultural en los ámbitos artístico, cinematográfico, literario o publicitario, resulta extenuante la labor de muchos autores por actuar con denuedo contra este sesgo. Como afirma Luís Bonino y cita Aguilar Carrasco (2006): "el acceso de las mujeres a la posición de sujeto del discurso ofrece a los hombres una oportunidad histórica inédita de observarse, por fin, en un espejo no deformante". Oportunidad que, en el caso del cine español, todavía estamos lejos de obtener, tal como veremos a continuación.

\title{
2. Metodología empleada
}

El método que hemos utilizado para este estudio es primordialmente el análisis de contenido de 600 películas españolas en que figuran periodistas, de las que hemos seleccionado 276 películas, por ser éstas en las que, en vista de sus sinopsis y sus fichas artísticas, se referencia una figura periodística femenina. De nuestro listado hemos descartado, no obstante, aquellos títulos de carácter sicalíptico, documental y de animación, por no adecuarse a los parámetros analíticos que se persiguen en esta investigación. Esta metodología se halla determinada por la propia naturaleza del estudio, fundamentada en la definición de las líneas generales que especifican tanto la figura de la periodista en el cine español, como el análisis de los contenidos éticos de los filmes examinados. Con esta aproximación hemos pretendido no sólo descubrir cuál es la imagen y los principios éticos presentes en las tramas de las películas propuestas, sino también inferir las relaciones que se establecen entre los distintos filmes en términos de evolución, estereotipos, temática y contenido ético. Dicha contigüidad ha sido cardinal a la hora de establecer correlaciones entre los argumentos y esbozar la línea evolutiva de los parámetros éticos y de imagen presentes en las distintas etapas que cronológicamente cubría la filmografía analizada. También nos hemos centrado en el análisis del filme como documento testimonial de un contexto espacio-temporal concreto, que representa los usos y costumbres de una época, y la interpretación que de la profesión periodística se ha hecho con el devenir del tiempo y los avatares sociopolíticos. Un método subsidiario será el análisis comparativo de la filmografía, a través del cual se pueden determinar los vínculos y correlaciones de la imagen de las reporteras; para ello se elaboró una ficha técnica con una serie de criterios de análisis englobados en dos bloques temáticos, a saber: la figura de la periodista y su ética. El motivo por el que se emplea una misma ficha técnica se nos antoja capital para homogeneizar y normalizar la amalgama inaprensible de aspectos relevantes que figuran en la filmografía analizada. 
Finalmente, también hemos empleado el método histórico, perspectiva que nos ha proporcionado las directrices necesarias para acercarnos al modo en que la cinematografía ha ido evolucionando desde un punto de vista cronológico. Dentro de este modelo histórico, destacamos dos puntos de vista fundamentales: la reconstrucción diacrónica de la trayectoria que han ido tomando tanto la perspectiva ética como la imaginería referida a las periodistas; y el análisis sincrónico del contenido de éstas, pudiendo establecer relaciones comparativas entre las imágenes y los postulados éticos presentes en los distintos filmes.

\section{El cine español y la mujer: qué he hecho yo para merecer esto}

Docilidad, entrega y belleza (Aguilar Carrasco, 2006), en estos términos podemos resumir la presencia femenina en la gran pantalla del cine español, una realidad que no tiene nada de sorprendente si tenemos en cuenta que el $80 \%$ de las películas dirigidas por hombres tienen protagonistas masculinos, algo nada banal atendiendo a las cifras que arrojan los últimos estudios del periodo 2000-2006, que lanzan la reveladora cifra de que sólo el 7,3\% de los filmes rodados durante este lapso, han sido dirigidos por mujeres ${ }^{2}$.

Por tanto, y como punto de partida, podemos hablar de una realidad axiomática incorruptible acerca del cine español, a saber: que la presencia de las mujeres, tanto delante como detrás de la cámara, resulta irrisoria en términos comparativos con la de los varones. El motivo podría asignársele a una suerte de paternalismo que ha dominado las estructuras de influencia desde la noche de los tiempos, un androcentrismo que ha sacudido todos los ámbitos sociales, desde los más nimios, hasta los más determinantes. Como señala John Stuart Mill en su afamado El sometimiento de la mujer (1896):

“[...] el conocimiento que el hombre ha podido adquirir de las mujeres, aunque no se trate más que de lo que ellas han sido o son ahora [...] es por desgracia muy imperfecto y superficial, y siempre lo será, hasta que las mismas mujeres hayan dicho todo lo que tienen que decir" (En VV.AA, 2003:19).

Esta perspectiva masculina, será la que impida un retrato fidedigno de la figura de la mujer, sin que un estereotipo haga prevalecer el "poder, dominancia o estatus" del hombre (Gómez en Morales, Moya, Gaviria y Cuadrado, 2007: 217) por encima de sus motivaciones y actos. A este respecto, destaca que durante todo el periodo estudiado - que corresponde a toda la filmografía española-, no se ha dejado de remarcar las diferencias sexuales, así como subrayar los estereotipos sociales atribuidos a cada género. En este sentido, "las definiciones de mujer y de hombre no son reflejo de una realidad preexistente, sino que son el resultado de una producción específica de diferencia sexual" (VV.AA, 2003:151), y así, el lenguaje fílmico (como todo lenguaje), estaría estructurado según las identidades y modos en que las normas de

\footnotetext{
${ }^{2}$ Declaraciones de Álex de la Iglesia en su discurso de investidura como presidente de la Academia de cine. 25 de junio de 2009 .
} 
nuestra cultura nos han ido modelando. Esta estereotipia, que en el caso de la mujer destaca por su simplificación y el desarrollo de prejuicios en su contra, ha sido marcada desde hace décadas, con expresiones, sentencias y admoniciones de disímil y fosca índole. Aunque se ha asociado al personaje femenino una serie confusa de categorías definitorias -"fascinación distante", "atractivo de la fragilidad", "femenino pasional y agresivo", "símbolo erótico" e "independencia" (Alonso Barahona, 1991: 36-37)-, en términos generales, podemos distinguir dos corrientes diferenciadas de cosificación de la mujer.

Por un lado, la damisela sumisa, servil y dócil, cuya vida estaba consagrada por principio a la satisfacción de padres, marido y sociedad; y por otro, la mujer "caída", perversa, inteligente, arpía y despreciable, que por osar ir contracorriente, era castigada como medida ejemplar. Ninguna de las dos tipologías obtiene el respeto de los hombres, ni el tratamiento positivo en las tramas, la primera por pusilánime y accesoria, la segunda por focalizar los vicios más profundos de la realidad social.

Ya en 1926, una producción elocuentemente titulada Frivolinas afirmaba “¡Mujer tentadora! ¡Mujer envuelta en todos los velos del pecado! En tus brazos quiero vivir... ¡O morir!", poniendo de manifiesto otra tendencia irrebatible en nuestro cinema: la mujer, en calidad de objeto deseable para un hombre -importante el sesgo del punto de vista narrativo-, representa aquello que aleja al hombre (el ser activo) de conseguir sus metas y objetivos. Y esta cuestión, que pueda parecer baladí, engloba otra realidad aún más evidente: las mujeres sólo pueden quedar subyugadas narrativamente a los momentos en que los hombres abandonan su actividad, sus asuntos trascendentales, y deciden retirarse al descanso de su ocio, encontrando a personajes secundarios que pululan a su alrededor para facilitar (y en su caso, complicar) la vida del hombre. Quizá el caso más corrosivo de cosificación femenina lo encontremos en la introducción del filme de Oti Mur, El batallón de las sombras:

"Dios creó al hombre a su imagen y semejanza y, al contemplarlo, se sintió satisfecho de su obra. Luego, para que Adán no se aburriera en el Paraíso, creó a la mujer, todos sabemos que, para lograr esta segunda criatura, le bastó al señor un simple huesecillo del hombre, y que el hombre, hombre al fin, y con perdón, el más perfecto de los animales, encontró muy agradable su costilla cuando, convertida en una criatura maravillosa, le dijo "me llamo Eva". Pero claro, las cosas se complicaron y vino el pecado y, con el pecado, la ira del señor. Y el hombre comenzó a fabricar trajes con hojas de parra y terminó levantando ciudades llenas de gigantescos edificios. Y esto lo hizo el hombre solo, completamente solo, y sin una costilla, bueno, sin una costilla pero con una mujer. Claro que, después de todo, qué significa una mujer en la vida del hombre, todo lo mas una compañía amable, amble algunas veces, pero nada más porque, seamos sinceros, ¿para qué sirve la mujer? Para nada, absolutamente para nada. Que nos cose los botones dice que nos estamos en casa cuando viene alguien a cobrar un recibo. Bueno, en algo ha de entretenerse. ¿Ah? Que nos trae al mundo... Sí señor, pero también nos trae algunas corbatas que no podemos ponernos. No quisiera parecer cruel pero, cuando vemos salir a los niños de un colegio, todos exclamamos convencidos jestos serán los hombres del mañana! Pero nunca hemos dicho ante un colegio de niñas que serán ellas las mujeres de mañana, ni del pasado mañana. Cuando un sabio como Flemming descubre la penicilina, proclamamos gracias a éste, se prologará muchos años la vida del hombre, pero jamás hemos oído decir que se prolongará muchos años ni muchos días, la vida de la mujer. Y es que todos conocemos al investigador famoso, al torero famoso, al artista famoso, y conocemos no sólo a los que triunfan y se coronan de laurel como un estofado cualquiera, sino también a los que 
caen vencidos en la lucha por el estofado. Pero nada sabemos de sus mujeres. Bueno, veo que algunos se resisten a admitir mis palabras, no piensan como yo que los hombres formamos el batallón luminoso de la sociedad, mientras las mujeres... Pues las mujeres son el batallón de las sombras. Eso es, el batallón de las sombras. Un batallón oscuro que combate en la trinchera cómoda del hogar".

Sería imposible esbozar una crítica a un determinado aspecto de esta introducción, habida cuenta de que su completo texto, de inicio a fin, atenta contra los principios básicos enunciados por la Declaración de Derechos Humanos, aunque quizá el hecho de que nadie piense en una niña como bastión activo de un futuro mejor sea un buen ejemplo de deconstrucción cultural. Así las cosas, no es de extrañar que el retrato de la mujer tienda a verse desvirtuado por su maldad, su impericia o su exuberante sexualidad, tres columnas sobre las que se sostiene la figura femenina en el cine español.

En este sentido, y siguiendo las directrices de pensamientos como el de Baudelaire (1896:145) cuando afirmaba que "la mujer era un objeto fatalmente sugestivo", no es de extrañar en las películas españolas de toda década, naturaleza y género, se encontrasen sentencias como: "es mi mujer y hará lo que yo diga" (El padre Manolo); "no deberían dejar conducir a las mujeres y menos llevando a sus propios hijos" (Es peligroso casarse a los sesenta); "a veces las mujeres son mucho más observadoras que los hombres" (El secreto de Bill North); "ha tenido una quinta criatura, cinco en seis años, eso sí que es cumplir con la ley de Dios" (Audiencia pública), o la reduccionista expresión referida a una joven en La malcasada: "en aquel ambiente tan nuevo para ella, ¿qué pensamientos entretendrían el pensamiento de la "virgencita"? Pensamientos de amor, naturalmente...". Sin embargo, si un discurso ha de ocupar el puesto de honor dentro de este somero listado de desafortunados estereotipos, éste lo representa el discurso final del filme paradigmático de esta patriarcal segregación, la citada El batallón de las sombras:

"Bueno, ya han visto ustedes que la mujer no representa nada en la vida del hombre. Pasarán los siglos y el hombre seguirá formando el batallón luminoso de la humanidad, mientras las mujeres serán siempre el batallón de las sombras. Porque nosotros ensalzamos a la mujer por nuestra reconocida cortesía o por un enfermizo romanticismo...".

En definitiva, un cúmulo de despropósitos que han contribuido, y mucho, a diluir la verdadera figura de la mujer en una marisma de recursos narrativos estereotipados, que la han reducido a mero accesorio masculino, bien como un pusilánime bastión de tranquilidad familiar, bien como precipitadora de sucesos negativos o, cómo no, ese "oscuro objeto de deseo", en términos de Buñuel ${ }^{3}$. El nuestro será un cine marcado por la diferenciación sexual, en que los roles femeninos quedarán bien definidos, y que nunca adquirirán la importancia o renombre que aquéllos interpretados por sus homólogos varones. En vista de estos resultados, veamos ahora si el estereotipo femenino se cumple o se subvierte, cuando la profesión atribuida a los personajes es el de mujer periodista.

\footnotetext{
${ }^{3}$ En referencia al filme franco-español de Luis Buñuel Ese objeto de deseo (1977), último de su carrera.
} 


\section{Mujeres periodistas en cifras}

Las mujeres periodistas no obtienen, ni por asomo, el mismo tratamiento que sus homólogos varones en el cine español. Así las cosas, de las 600 películas en las que aparecen periodistas, sólo en 276 (46\%) las reporteras son mujeres; de un total de 1759 periodistas (de los que sólo 630 son mujeres -35,81\%-frente a los 1129 varones), éstas sólo adquieren un rol importante en 120 títulos (20\% del total de filmes). Con este dato, comprobamos cómo la existencia de mujeres periodistas resulta exigua en comparación con la de sus compañeros varones.

Asimismo, sorprende que de las 278 ocasiones en que los periodistas hombres actúan de forma autónoma, tan sólo en 50 ocasiones las mujeres periodistas acudan de manera independiente, sin compañía masculina. También resulta impactante que el número de mujeres presentadas en grupos dispersos, sea de un máximo de 10 periodistas juntas, en contraposición a los más de 27 hombres que llegan a estar unidos en un mismo evento informativo. Una evidencia que, a pesar de los condicionamientos coyunturales del contexto socio-político, no deja de resultar patente incluso a día de hoy, cuando el rol del periodista principal en nuestro cine sigue recayendo sobre el profesional varón.

Con todo, y pese a no ser tan avanzados en materia de mujeres periodistas como en otros países, las informadoras españolas de ficción serán activas e independientes en 95 filmes $(34,42 \%)$, de las que serán extremadamente independientes y activas en 48 filmes (17,39\%), mostrándose pasivas sólo en 3 filmes $(1,21 \%)$, así como adolecerán de engreimiento y jactancia en 38 ocasiones $(13,76 \%)$. En 28 títulos $(10,14 \%)$ las periodistas femeninas serán malvadas, representando el eje ignominioso del filme, ora siendo las culpables de alguna exceso, ora hostigando, castigando o abusando de su poder. Finalmente, de las 630 periodistas que se muestran en nuestra ficción cinematográfica, tan sólo dos de ellas están embarazadas $(0,31 \%)$.

\subsection{Las periodistas en el cine español: entre vamp y femme fatale}

Soy una mujer fría y calculadora que te llevará a la perdición Asesinato en el Comité Central

Si tal como venimos indicando, las mujeres en el cine se encuentran "estereotipadas en imágenes de objetos sexuales víctimas o vampiros" (García Rayego, 2010: 7), la generalidad de los casos de mujeres periodistas en el cine español, adoptarán el rol de lo que ha venido a denominarse como vamp o femme fatale, según la crítica cinematográfica. Este hecho entroncaría, tal como apunta el gran historiador Román Gubern (1993), a una perversión en el concepto de afirmación femenina, en el que se confundido autonomía por adulterio. Como el propio autor expone:

\footnotetext{
"Todas estas cuestiones se han infiltrado en algunas fabulaciones cinematográficas de Hollywood, en temas tales como la afirmación de la autonomía femenina mediante el adulterio o el cambio de personalidad de la mujer tradicional. En la producción literaria había abundado sobre todo la
} 
adúltera por cálculo (cuyo modelo arquetípico se halla en la Betsabé bíblica) y la adúltera por mitomanía (como Madame Bovary). En el cine reciente se ha hecho cada vez más frecuente la presentación del adulterio femenino como acto de autoafirmación de identidad y de emancipación personal". (Gubern. 1993:161).

Esta elección argumental en la ficción que aborda el periodismo tiene una explicación ciertamente definida. Ya hemos mencionado que el periodismo es una profesión de personajes cínicos, ácratas, en aspectos inmorales y muy independientes.

Figura 1. Ejemplo de una de las periodistas femme fatal del cine español: Oviedo Express

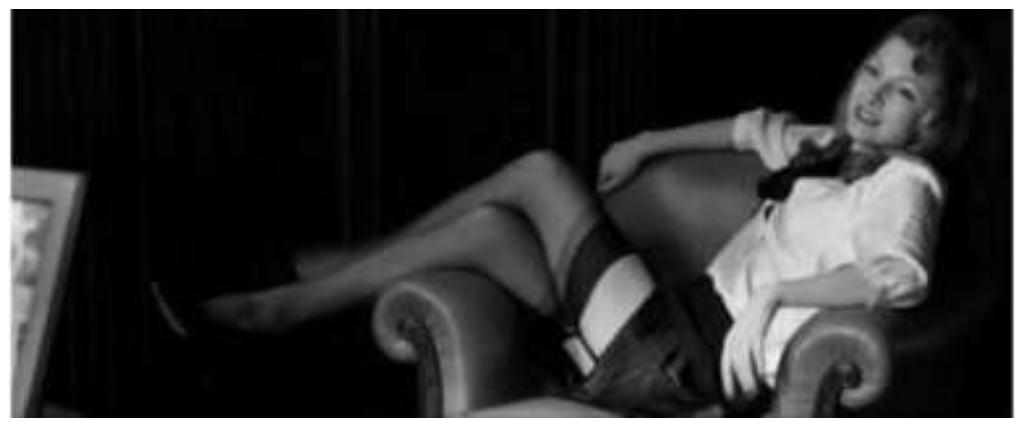

Fuente: fotograma de Oviedo Express - elaboración propia

También hemos citado que las mujeres ejemplificantes en la industria cinematográfica son pasivas, bellas, dulces y dóciles; al contrario que las maléficas del cinema, que suelen pecar exactamente de descompostura, autonomía y asertividad. Ergo si a esta feminidad insolente se le añade el sesgo de una profesión de cinismo descocado, el resultado será el de unas periodistas que se comportan no sólo del modo impío en que lo hacen los hombres, sino que se les impondrá, por añadidura, características de maledicencia atribuidas, en exclusiva, a las mujeres.

Los personajes femeninos adolecerán no sólo del descaro propio del estereotipo periodístico, sino que sufrirán el doble marcaje de un carácter indomable propio de una mujer que actúa "contra natura" -entendiendo por lo "naturalmente establecido" el prototipo de mujer pasiva y sumisa-.

Por otro lado, este aspecto de doble presión sobre la mujer informadora no sorprenderá dentro del ámbito periodístico, pues es bien sabido -y registrado en distintos estudios, como el de Linda Steiner en 1998-, que las profesionales de la información se ven sometidas de facto a un estatus similar a sus homólogas de ficción:

"Las profesionales de los medios están sometidas a una situación normativa de doble vínculo. Si rehúsan comportarse en el trabajo de acuerdo con pautas consideradas como "femeninas" son tratadas como "desviantes" y si aceptan, son marginadas. En las redacciones y en las emisoras de televisión se espera que las mujeres sean "asertivas" pero no "arrogantes", agresivas pero no "inapropiadamente masculinas" (VV.AA, 2003:43). 
Gráfico 1. Evolución de la presencia de mujeres periodistas en el cine español

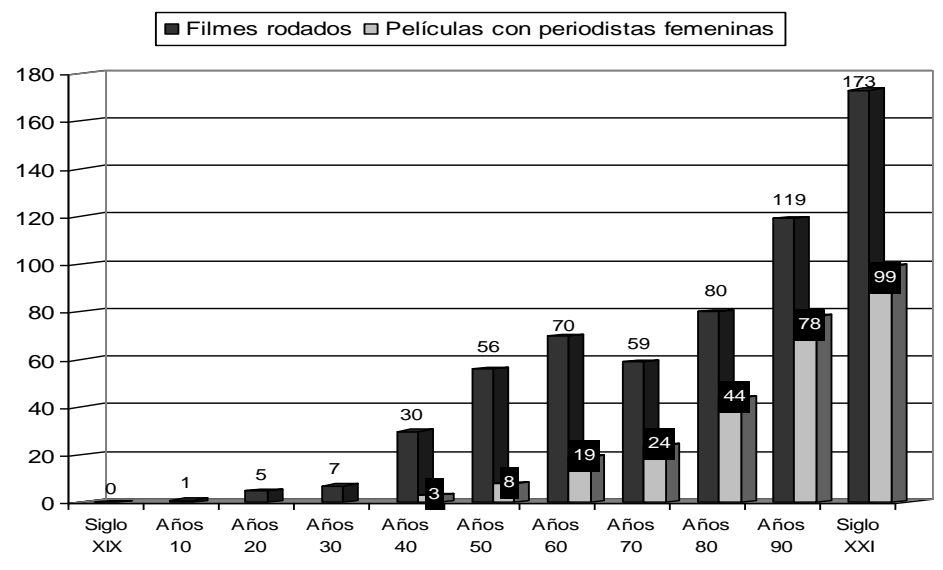

Fuente: elaboración propia

En términos estadísticos, la realidad de las periodistas de ficción cinematográfica resulta mucho más esclarecedora. De las 276 películas (46\%) en que salen mujeres informadoras, y de un total de 630 periodistas mujeres incluidas en las tramas (35,81\% del total), éstas sólo adquieren un rol importante en 120 películas (20 del total de filmes).

A pesar de los descorazonadores datos, la representatividad de la mujer en las tramas ha avanzado de forma lenta pero espectacular, pasando de tres únicas periodistas con un rol medianamente relevante en la trama en la década de los años cuarenta, a las ochenta periodistas que ocupan esa importancia narrativa en la primera década del siglo XXI.

Esta realidad podría parecer consustancial a la cinematografía mundial, aunque lo cierto es que el retraso en lo que a materia de igualdad que arrastra nuestra industria es notable, pues en países como Estados Unidos, la primera película que aborda la realidad de las mujeres en el periodismo - este matiz es importante, pues no hablamos siquiera de un rol vertebral para la trama sino que toda ella gire en torno a una fémina reportera-, versa de 1909 , con el film $A$ Female Reporter.

Aunque no tan avanzados en materia de mujeres periodistas como en otros países, las informadoras españolas de ficción serán en 95 filmes $(34,42 \%)$, mujeres activas e independientes, de las que serán extremadamente independientes y activas en 48 filmes (17,39\%). Asimismo, se mostrarán pasivas sólo en 3 filmes (1,21\%), así como adolecerán de engreimiento y jactancia en 38 ocasiones (13,76\%). En 28 títulos $(10,14 \%)$ las periodistas femeninas serán malvadas, representando el eje ignominioso del filme, ora siendo las culpables de alguna exceso, ora hostigando, castigando o abusando de su poder).

"Desde el principio, las mujeres reporteras eran independientes, damas endurecidas, preparadas y dispuestas a hacer cualquier cosa que sus compañeros varones harían por conseguir una historia. La sobsister siempre se prueba a sí misma. Tiene que persuadir a los hombres que la rodean de 
que es valedora de su respeto. Normalmente fastidia antes de ganar sus galones, pero a la larga, es una reportera trabajadora e independiente que nunca deja caer a su periódico" (Saltzman, 2002) ${ }^{4}$.

En líneas generales, es éste también el retrato de la fémina reportera en la ficción española. "Agresiva, segura de sí misma e independiente" (Ghiglione y Saltzman, 2002: 9), en ocasiones rozando el estereotipo masculino, a pesar de constituir, en su mayoría, un bloque homogéneo de féminas "jóvenes, inteligentes, refinadas y atractivas" (Ghiglione y Saltzman, 2002: 9). En ciertos casos, como lo es el de la película Cuarenta años sin sexo, esta tendencia a la agresividad e independencia femenina es retratada a medio camino entre la loa y la crítica, como puede observarse en el párrafo introductorio a la figura de Ana, una redactora muy peculiar:

\begin{abstract}
"Ana ha adquirido gran renombre por sus artículos polémicos, sangrantes, casi en contra del machismo. Ana es una mujer interesante aunque un poco incómoda. Cuando uno se reúne con ella lo más probable es que surja la discusión. Ahí la tienen ustedes, hoy más excitada que de costumbre porque se le ha metido entre ceja y ceja realizar un concurso-reportaje con el que piensa demostrar que el hombre más pintado (sexualmente hablando), es un animal inferior a la mujer. [...] Se trata de encontrar al hombre más macho entre los machos, que esté dispuesto a acostarse con una vedette de nuestro cine. La tesis que quiere demostrar nuestra compañera es que el machismo es un gigante con pies de barro".
\end{abstract}

Pese a la imagen autoritaria que en la generalidad de los casos se aporta de los personajes femeninos periodistas, sólo una pequeña proporción alcanza la posición de liderazgo en la jerarquía de poder mediática (Slam, Di que sí, Salvaje, El año que trafiqué con mujeres, Mamá es boba y Al final del camino). Es más, en contra de la tendencia psicosocial de atribución de rasgos estereotípicamente masculinos de las mujeres líderes (entendiendo por tales aquéllas que ocupan puestos de relevancia jerárquica en una empresa), en nuestro cine estos rasgos se le asignan a las reporteras rasas. La diferencia de este matiz es fundamental, pues según las teorías psicosociales, los subordinados muestran diferencias en su sistema de valores con respecto a los líderes, máxime en el caso de las féminas. "las comparaciones entre líderes y subordinados/as muestran que las principales diferencias se producen entre las mujeres, de forma que las líderes otorgan más importancia que las mujeres que no desempeñan estos roles a los valores que sirven a intereses «individualistas»" (Cuadrado, 2004: 274).

Por este motivo extraña que, al contrario que en los usos sociales, donde a una mujer con alto grado de asertividad y autoridad suele corresponderle una posición jerárquica de líder, en el cine español sea esa tendencia precisamente la de una redactora o reportera sin un puesto de gran responsabilidad, al mismo tiempo que llama la atención que, haciendo alarde de tales valores estereotípicamente masculinos, la mujer periodista en el cine no llegue a ocupar puestos de poder. Como puede observarse, éste es otro aspecto en el que el cinema se desvincula de la realidad circundante. En otro orden de cosas, existe un dato anecdótico que bien puede servirnos para comprobar el grado de "masculinización" al que son sometidas las mujeres periodistas, no tanto por el hecho de que realicen en exclusividad tareas que histórica y patriarcalmente han sido atribuidas al sexo masculino, cuanto por evidenciar

\footnotetext{
${ }^{4}$ La traducción es nuestra.
} 
hiperbolizadamente estas tareas. Así las cosas, sorprende que de los catorce casos en que una mujer conduce -sólo dos modelos de flamantes coches: bien todo-terrenos, bien utilitarios rojos y resplandecientes-, a tres féminas les toca cambiar una rueda ${ }^{5}$, hecho que no se registra, por otro lado, en el caso de ningún reportero varón. Asimismo, destaca que de las 630 periodistas que se muestran en la ficción cinematográfica, sólo dos de ellas estuvieran embarazadas $(0,31 \%)$, tanto la redactora de televisión en Entre el cielo y la tierra; como la citada jefa de una publicación femenina en Al final del camino. También Cristina Marcos interpreta a una trabajadora de televisión que acaba de dar a luz y esto le acarrea serios problemas profesionales en Insomnio, pero a este caso particular le daremos tratamiento específico en próximos capítulos.

Resulta curioso que, al contrario que en los casos norteamericanos, donde "los guionistas varones, quizá preocupados porque estas periodistas eran demasiado independientes y batalladoras para su tiempo, se aseguraban de que al final del metraje, estas mujeres autosuficientes sucumbieran al amor" (Saltzman, 2002), en España casi ninguna mujer acabe pereciendo (en sentido figurado) ante el amor, es más, en la mayor parte de los casos son los hombres periodistas los que terminan echando por tierra sus rígidos idearios por estar al lado de las mujeres en cuestión, sean o no compañeras de profesión. Tan sólo en doce películas ${ }^{6}$, las periodistas acaban dando su brazo a torcer y entregarse a los placeres del amor romántico, a pesar de que son muchos los filmes en que se relata el amor que sienten las informadoras; sin embargo, todos ellos tienen en común que para las periodistas, lo más importante es su profesión, por encima de sus sentimientos o los que puedan ellos suscitar en sus compañeros. Incluso en la paradigmática Escuela de Periodismo, el final revelador deja patente que la joven periodista no va a perder su vocación para promocionar a su pareja, sino que ésta va a prevalecer sobre todo tinte romántico.

En esta línea discurre Gary Cooper que estás en los cielos, con una realizadora televisiva que obvia a su compañero sentimental periodista cuando observa en él liviandad; al igual que Lola, la coprotagonista de Solos en la madrugada, quien decide irse a Londres a pesar del amor encubierto que siempre ha sentido por su compañero. Otras películas en que las periodistas son las que marcan la pauta de acción en de las vinculaciones sentimentales serán El día de los enamorados, Crimen en el entreacto, Entre abril y julio, El coronel Macià, filmes en que son los hombres los que caen prendados por las féminas, a pesar de que ellas se niegan a establecer algún contacto con ellos, o bien se mantienen dignamente enamoradas en silencio hasta que ellos dan el primer paso. Incluso si son ellas las que provocan situaciones embarazosas con sus parejas o colegas profesionales (como femme fatale), no se inmutan a la hora de poner las cosas claras y separar perfectamente lo profesional de lo personal ${ }^{7}$.

\footnotetext{
${ }^{5}$ En este caso, hay que matizar que a Carmen Maura en Cómo ser infeliz y disfrutarlo le toca cambiar una rueda sin que ésta fuera conduciendo el coche.

${ }^{6}$ Historias de la radio, Enseñar a un sinvergüenza, Al servicio de la mujer española, Gorilas a todo ritmo, En la cresta de la ola, Tacones lejanos, Vivir así, Canícula, Escuela de seducción, El año que trafiqué con mujeres y Al final del camino).

${ }^{7}$ Como sucede en Cómo ser mujer y no morir en el intento, Cómo ser infeliz y disfrutarlo, El escote, Relaciones casi públicas, Barrios altos, Puede ser divertido, Catorce estaciones, La ley de la frontera, Territorio comanche, Érase otra vez, Tinta roja, Mariposa negra, Días de boda, Diario de una becaria, Excuses, Bienvenido a casa, El desenlace o Cámara oculta.
} 
Sin embargo, las periodistas que representan con mayor fuerza y contundencia el rol de auténtica vamp son Najwa Nimri y Mónica Randall, la primera en su papel de cronista de la ciudad en Oviedo Express, donde aparece ataviada con cortas minifaldas, camisas con pronunciado escote, carmín rojo y mirada desafiante, llegando a afirmar que tiene "el corazón entre las piernas", así como la segunda en Catorce estaciones, donde despliega sus hechizantes encantos a golpe de glamour y carmín bermellón, ganándose el título de "Hidra", en honor a la mítica serpiente policéfala que acabó dando muerte Heracles, y que nos da una idea del concepto que de la periodista posee su entorno. Destaca igualmente que, a pesar de que muchas periodistas tengan como pareja o ex pareja a su compañero informante, esto no sea óbice para que sean brillantes y además admiradas por el resto de su profesión, manteniendo por lo general (no siempre), su relación en secreto, para que no existan rumores de intereses personales por encima de los profesionales. Así sucede en Asalto al banco central, El secreto de Bill North, El reportero, Corazón de papel, Los reporteros, El baile del pato, Disparate nacional, De amor y de sombra, Mamá es boba o Atilano Presidente. Finalmente, debemos citar que sólo diez periodistas, de los más de cuatrocientos personajes aparecidos en nuestra filmografía, hacen alarde de lo que históricamente se ha conocido como el talante femenino, siendo dóciles, sumisas y además de una bondad exquisita, sin que las lacras de ser periodista en un universo masculinizante les hayan hecho mella alguna.

\subsection{Características personales: desnudos, sexo y prostitución}

- Yo creía que los escritores erais más viciosos - Sólo los buenos. ¿Qué he hecho yo para merecer esto?

Otro de los puntos comunes en nuestra cinematografía, es el manido recurso al desnudo. Y hablamos de conocido porque es vox populi que el cine español emplea con obstinada frecuencia la desnudez para establecer cierta conexión con el público. Este hecho no resulta en absoluto novedoso, habida cuenta de que desde los años del destape, el desnudo -en concreto el femenino-, ha sido una constante en nuestra cinematografía. Evidentemente, los periodistas no podían sustraerse a esta tendencia.

Así, en 23 títulos de nuestra filmografía $(3,8 \%)$, se muestra una escena de sexo, siendo 11 de ellas $(1,83 \%)$ en situaciones de infidelidad. Además, resulta sorprendente que se llegue a mostrar escenas de tríos, tanto femeninos como masculinos; en el primer caso, promovido por la redactora de Mariposa negra con dos varones; así como de un redactor de respetable edad con dos jovencitas en Las huellas del lince; y de un locutor radiofónico con dos (y hasta tres) desconocidas en El donante.

Respecto a los desnudos, con un total de 21 , encontraremos 13 femeninos $(61,9 \%)$ y 9 masculinos $(42,85 \%)$, podemos observar cómo los periodistas se despojan de sus prendas en películas como Barrios altos, Demasiado para Gálvez, El desenlace, Asesinato en el comité central, Diario de una becaria, Las dos orillas, El escote, Fuga de Ceilán, Al servicio de la 
mujer española, Gorilas a todo ritmo, Las huellas del lince, No te fallaré, Los reporteros, El socarrón, Territorio comanche o La triple muerte del tercer personaje. Huelga decir que en casi todos los casos el desnudo es gratuito, pudiendo prescindir de él en todas las producciones.

De la misma manera, y a pesar de que hemos desechado las películas de índole pornográfico, debemos subrayar el carácter altamente erótico de títulos como La fuga de Ceylán y El escote, quizá más justificado en el último título, aunque excesivo en todo caso. Y todo ello porque explotar la silueta femenina es una constante en el cine español, bien mostrando el cuerpo entero, bien ilustrando las voluptuosidades corporales en segmentos, en una suerte de "colección de piezas de mecano" (Aguilar Carrasco, 2006) que fracciona y cosifica a la mujer en la generalidad de los filmes.

Esta preponderancia del cuerpo en la industria audiovisual (no únicamente en la cinematográfica), es un hecho que desde largo se ha venido estudiando en el mundo de la significación de los medios. Roland Barthes (2001) ya menciona en su paradigmático Mitologías, el valor simbólico del desnudo (en concreto, el del strip-tease), que podemos extrapolar al caso del desnudo en el cinema:

"El strip-tease [...] está fundado en una contradicción: desexualiza a la mujer en el mismo momento en que la desnuda. [...] El público se constituye en voyeur únicamente por el tiempo que dura el desnudamiento. Pero en este caso, como en cualquier espectáculo mistificante, el decorado, los accesorios los estereotipos sirven para contrariar la provocación del propósito inicial y terminan por sepultar todo en la insignificancia: se muestra el mal para perturbarlo con más facilidad y exorcizarlo. [...] procedimiento de mistificación que consiste en vacuna al público con una pizca de mal para poder arrojarlo en seguida, con mayores posibilidades de éxito, inmunizado, a un Bien Moral. Algunos átomos de erotismo, recortados por la propia situación del espectáculo, son absorbidos en un ritual tranquilizante que obra la carne de la misma manera que la vacuna o el tabú fijan y contienen la enfermedad o la falta" (Barthes, 2001: 150-151).

Al respecto, es paradójico que, llevándose la industria española por un recato exacerbado en las féminas hasta llegar al paroxismo, se permita a las mujeres periodistas un tipo de conducta "licenciosa" propia de las mujeres a las que de continuo se les castigaba en las tramas. Así es que se puede deducir que, mediante un procedimiento de redención y venganza, a las mujeres a partir de los años setenta se les hizo valedoras de todo aquello que se había prohibido y hasta censurado en la conducta femenina. No en vano:

"Los rituales íntimos del amor debían resultar entonces algo muy complicado, sobre todo para la mujer, obligada socialmente a la castidad, a mantener su virtud y hacer gala de ella en todo momento. Cualquier efusión sentimental tenía que ser, por fuerza, clandestina, y conllevaba los riesgos del escándalo y el castigo si era descubierta" (Romero, 2001).

En honor a la verdad, pocas son las periodistas de ficción que hacen gala de esa castidad a la que Vicente Romero alude, máxime cuando se vincula la sensualidad en la mujer, con la inmoralidad. Salvo las provenientes de las décadas de la posguerra y hasta los años setenta, "siempre había una mujer mala" (Zúñiga, Ángel en Romero, 2001), esto es, una mujer que hace honor de las características propias de sus homólogos varones: 
"El hombres siempre fue distinto a la mujer y lo que en los personajes femeninos se producía en tragedia, en los masculinos adquiría tintes de comedia. La moral sexual era, y sigue siendo tantas décadas después, una doble moral, con dos medidas muy distintas. La mujer, que no debía caer jamás en la tentación, podía ser, sin embargo, objeto de tentación para el hombre" (Zúñiga, Ángel en Romero, 2001).

$Y$ en efecto, en el cine español la mujer siempre resulta una tentación para sus compañeros masculinos. Este hecho se observa también en otro aspecto del que no se sustraen hombres ni mujeres periodistas, éste es: el de la prostitución. Por supuesto, el matiz diferenciador lo aporta en este caso la atribución de roles de cliente y profesional, ya que hasta en 6 producciones (1\%), las reporteras llegan a prostituirse por la consecución de un determinado deber profesional, o bien porque consideran que el ceder su cuerpo es la única vía de conseguir sus propósitos. Así, en Viva la muerte... Tuya, la corresponsal norteamericana debe entregarse a un militar caciquil de México para ayudar a sus compañeros de viaje a hacer la revolución. Como indica uno de ellos: "Si una chica sola quiere hacer la revolución, tiene que sacrificarse de alguna manera. ¿Sabes? No, no te hagas ilusiones. Vestida o desvestida a nosotros no nos interesas, pero a un viejo necio como el general sí puedes interesarle, ¿está clara la idea?".

En otras películas como Un negro con saxo o en la reciente El año que trafiqué con mujeres, las periodistas también se prostituyen. En éste último filme, Raquel Meroño interpreta a una profesional de la televisión ambiciosa que afirma "veo cómo otras se hacen famosas y yo no quiero quedarme atrás. No voy a quedarme atrás", y que decide adentrarse en el universo de los futbolistas de elite para descubrir el entramado de meretrices que presuntamente abunda en ese terreno. Su compañero, quien es capaz de decirle: "fama vas a tener toda la que quieras, pero prestigio... poquito", se hace pasar por un proxeneta para conseguir su exclusivo reportaje. Cuando su compañera se entera de la desigualdad de papeles repartidos, no duda en increparle: "Lo que quiero es que pongas los cinco sentidos en este reportaje, porque yo estoy poniendo bastante más, ¿o te crees que es divertido lo que hago? Porque si quieres cambiamos, y que te folle un gilipollas que se cree tu dueño mientras tú tienes que reírle las gracias, ¿quieres?”.

Finalmente, tampoco hace un craso favor a la profesión la presentadora televisiva Beatriz "The Best", en la trilogía de Pinzás Érase otra vez, Días de boda y El desenlace. En esta última, la informadora, con nulo sentido corporativo, llega a responder a una exclamación retórica de un compañero: “CCómo sois las de la televisión!”, con la siguiente sentencia: “La mayoría unas putas, pero yo estoy loca por ti”. Por supuesto, y como no podía ser de otra forma dado el histórico carácter del cine español, a estas mujeres se les castiga duramente, bien dándoles un repaso a su vida a través de discursos vejatorios de índole paternalista -cuando no machista-, bien condenándoles argumentalmente a la destrucción o desaparición. Y es que, "todas las pecadoras del cine español fueron condenadas a la enfermedad o la muerte cuando no a la clausura. Sólo pecaban las mujeres" (Galán, Diego en Gubern, (2000):127). Los periodistas varones de nuestra ficción, sin embargo, no dudan en acudir a los servicios de meretrices, como una actividad de normalidad extrema, estando presente en innumerables 
conversaciones y escenas. En El baile del pato, por ejemplo, los periodistas varones afirman: “todas las mujeres necesitan un príncipe azul. Y los hombres una mujer y muchas putas". En El hueso, el informador protagonista de la cinta no mostrará reparo alguno al acudir al servicio frecuente de meretrices, así como En la línea del cielo, el fotógrafo protagonista mantiene una conversación con un amigo en la que denominar a algunas mujeres "cobrizas" (en su calidad de cobradoras), es moneda de cambio habitual. En definitiva, el fenómeno de la prostitución visto desde dos puntos de vista muy distintos, en ninguno de los cuales se atiende a la verdadera dimensión de la problemática que deriva de la trata y explotación sexual de las mujeres.

\subsection{Violencia y sexualidad: arquetipos, agresiones y otras lacras}

Un hecho que ciertamente llama la atención en toda nuestra cinematografía, es la tendencia a reflejar una de las peores lacras de la sociedad española, ésta es, el maltrato a la mujer. El cine patrio tampoco se mantiene ajeno a esta realidad vergonzante, sometiendo a nuestras mujeres de ficción a un constante contacto con la violencia; un abuso que, por otro lado, llega a disgustar de tan manido y frivolizado. La violencia personal, institucional y hasta estructural del que hacen alarde nuestras películas, no deja de ser un atroz indicativo de cuál es el grado de penetración de los valores subyugantes de la mujer que inculcó el modelo patriarcal tradicional. Ya hemos hablado de la violencia simbólica que supone el reducir a la mujer a un estereotipo determinado en el seno de la sociedad y de los medios, a través de un "código hegemónico de representaciones [que] opera a través de la sujeción cultural de grupos sociales minoritarios, esos otros definidos por un determinado género, raza, sexo, edad..., fijándolos como signos mediante la estereotipación, la exotización y la marginación, erradicando y consumiendo la diferencia” (Bernárdez, García y González, 2008:49).

En este sentido, nos interesa ahora imbuirnos en el estudio de la violencia directa ejercida sobre las mujeres (en sentido figurado, por supuesto, al tratarse de una interpretación), para dar cuenta del grado de aceptación que este tipo de violencia ha tenido cabida en nuestra sociedad. En boca de personajes que nada tienen que ver con el periodismo, en el cine español se enuncian infames descomedimientos acerca de la violencia machista como los que siguen: "Estás muy guapa, te quedan bien los golpes" (Barrios altos); "a la suerte, como a la mujer, hay que enseñarle el puño" (Best seller); “¿Tú crees que con la lata que da una mujer, voy a meterme con otra?" (Alcalde por elección); "Si no fuera usted tan bonita, le daría unos azotes" (Un ladrón de guante blanco). Frases que resultan del todo normales, enunciadas aun en tono cómico, y que se muestran como extraordinariamente insensatas si se analizan pormenorizadamente. No obstante, si hablamos de auténticas ofensas al buen gusto y al sentido común, éstas se encuentran en canciones como la que las hermanas Hurtado canturrean a viva voz en En busca del huevo perdido, con letras tan denigrantes como esta:

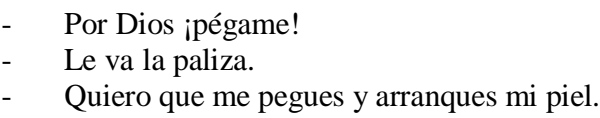


Semejante es el diálogo que mantiene un matrimonio entrado en años en el filme Maravilla, donde una esposa, viendo la expresión amenazante de su marido, le espeta "No, si me pegarás una paliza...", a lo que el marido responde "es una ilusión que tengo desde antes de casarnos, pero luego vino la guerra". Sin embargo, si de ofensas contra los derechos humanos se trata, sin duda es Surcos el mejor ejemplo de lo que era España en la década de los años cincuenta (cuyos rescoldos siguen vivos y humeantes hoy en día, tal como informan a diario los medios), y cuál es el calado moral de la violencia machista patria en toda su extensión. Frases semejantes a: "como yo sé de mujeres, pues las trato mal y voy en coche"; "te daré tres sopapos, que es lo fetén, pero después enamorados como dos palomas"; "en situación semejante mi marido me dejó para siete días de cama"; "éste [pegar] es el mejor argumento que se puede esgrimir con las mujeres", son las perlas que nos regalaba en Surcos, declarada obra de interés nacional y que constituye, machismo y violencia aparte, una de la cintas cumbres de la década. En este contexto de permisibilidad y aun amparo de la violencia, no es de extrañar que también los periodistas beban de esta misma fuente violenta. Personajes como el del informador gráfico que interpreta Máximo Valverde en Las Ibéricas F.C., mantiene una estructura de dominio tal sobre su novia -jugadora del club de fútbol que da título a la cinta-, que ante su mera presencia, huye a esconderse en los vestuarios. Ante el miedo que siente la joven, una compañera (lejos de apoyarla y escandalizarse con ese caudillaje), aumenta su miedo y se ríe a su costa:

- ¿Qué haces?

- $\quad$ No te muevas. Mi novio está ahí [...] Con lo grande que es España y ha tenido que venir aquí, con la de fotógrafos que hay.

- ¿Ese tipazo es el que te pega?

- Esta vez no me da una bofetada, me da una paliza.

- $\quad$ Pues mejor, es lo que te gusta.

- $\quad$ Quién se lo habrá dicho... Soy una desgraciada.

- Si quieres le llamo par que te peque ahora, así entras en calor.

- ¡Ni hablar!

Con reacciones semejantes de las propias mujeres, no sorprende que el comportamiento del periodista no sólo no sea recriminado, sino que además la perspectiva de la película le haga aparecer como un dandy seductor y exitoso con las féminas, que demuestra su virilidad a golpe de violencia. Otras películas en que distintos periodistas aparecen golpeando una o repetidas veces a alguna mujer son Imposible para una solterona, Esposa y amante, El transexual, testigo azul, El socarrón o Tres noches violentas. Desde la óptica opuesta -la perspectiva de las mujeres periodistas-, encontramos que también éstas sufren el maltrato de algún compañero, como sucede en Salvaje o Enseñar a un sinvergüenza, en contraposición a la única informadora que arremete contra un compañero, Victoria Vera como fotógrafa de prensa en Gorilas a todo ritmo, y sólo porque éste le había lisonjeado insistentemente a pesar de sus advertencias. 


\section{Conclusiones}

Después de todo lo expuesto, resulta evidente que la presencia de mujeres periodistas en nuestro cine ni es profusa ni tampoco ejemplificadora. Su escasez de número (apenas un $35,81 \%$ del total de periodistas que figuran en las 600 películas que conforman nuestra investigación), añadido a las características negativas de las que hacen alarde, ilustran un panorama cinematográfico poco o nada alentador.

Y es que salvo limitadas excepciones, la generalidad de nuestras periodistas estarán representadas en la ficción por unas mujeres valedoras de un espíritu indomable, cuya disposición personal siempre va dirigida a maximizar sus cualidades periodísticas, desdeñando el amor o simplemente colocándolo en una posición subordinada a la realidad laboral. De lo que no cabe duda, es de que estas mujeres, retratadas como el paradigma de la maldad en la generalidad de los casos, llevan en su interior un gran peso y responsabilidad pues, como bien afirma nuestro internacional Almodóvar "las malas siempre sufren más que nadie, porque la capacidad de maldad empieza en uno mismo" (Bonet Mójica, citado en Caparrós Lera, 1992:322). Quizá por ello su capacidad profesional sea de intachable valía, y su vida personal, en cambio, deje tanto que desear. Por supuesto, en nuestro cine a estas mujeres indóciles se les censura, recrimina y critica, haciendo de su perdición un castigo ejemplar para la casta periodística en concreto, y para el sexo femenino en general. En resumidas cuentas, todo un rosario de aspectos difíciles de asimilar en su conjunto, que nos hace replantearnos la peligrosidad del concepto de mujer que el cine nos ha inoculado a lo largo de su historia, así como los valores que han regido nuestro tiempo de ocio y esparcimiento cinematográfico. Con independencia de la profesión de la que haga alarde la mujer en el cine, aunque en especial nos incumba lo que a las periodistas se refiere, resulta evidente que éstas siempre han sido interpretadas como meros apéndices al amparo de un hombre que les dé el honor y la seguridad que necesitaban. Así no resulta extraño el hecho de que, al aparecer personajes femeninos que rehúsan ser tratadas como meras comparsas, el cine acabe arrinconándolas o retratándolas como mujeres fatales, sugestivas, tan peligrosas como fascinantes, pero a las que, por si acaso, vale más tener a cierta distancia.

Quizá por eso la generalidad de las periodistas en el cine español sean mujeres solteras: tal vez los hombres no están preparados todavía (al menos en la ficción) para el indómito carácter de la mujer informadora. 


\section{BIBLIOGRAFÍA}

- Aguilar, Pilar (2002): "La violencia contra las mujeres en el relato mediático". En Claves de la razón práctica, $\mathrm{n}^{\circ} 126$, pp. 75-78.

. (2006): "Una mirada crítica sobre el cine español”. En Estudios feministas, Juniodiciembre, [en línea] Disponible en: www.unb.br [10/11/2011].

- Alonso Barahona, Fernando (1991): Antropología del cine. Colección Cine-Ensayos. Barcelona: Centro de Investigaciones Literarias Españolas e Hispanoamericanas.

- Barthes, Rohland (2001): Mitologías. (1ºdición 1980). Madrid: Siglo XXI de España.

- Baudelaire, Charles (1896): Pequeños Poemas en Prosa. Los Paraísos Artificiales, p. 145. En Charles Baudelaire y Thomas De Quincey (1890): Les Paradis artificiels: Opium et hachisch. París: Poulet-Malassis et De Broise.

- Bernárdez, Asunción; García, Irene y González, Soraya, (2008): Violencia de género en el cine español. Análisis de los años 1998 a 2002 y guía didáctica. Madrid: Editorial Complutense.

- Caparrós Lera, José María (1992): El cine español de la democracia: de la muerte de Franco al "cambio socialista (1975-1989). Barcelona: Anthropos. Palabra plástica.

- Cuadrado, Isabel (2004): "Valores y rasgos estereotípicos de género de mujeres líderes”. En Psicothema, Vol. 16. $\mathrm{n}^{\mathrm{o}}$ 2, pp: 270-275.

- García Rayego, Rosa (2010): "Mujeres, arte y literatura: imágenes de lo femenino y feminismo". Publicaciones del Instituto Feminista de la UCM, [en línea] Disponible en: http://www.instifem.org/Portals/0/PropertyAgent/399/Files/28/Cuadernos -

Mujeres, \%20arte\%20y\%20literatura.pdf [05/10/2011].

- Ghiglione, Loren y Saltzman, Joe. (2002): "Fact or fiction. Hollywood looks at the news", [en línea] Disponible en: http://www.ijpc.org/uploads/files/hollywoodlooksatthenews2.pdf [12/11/2011].

- Gubern, Román (1993): Espejo de fantasmas. De John Travolta a Indiana Jones. Madrid: Espasa hoy.

- Morales, J. Francisco; Moya, Miguel C; Gaviria, Elena y Cuadrado, Isabel (coord) (2007): Psicología social. Tercera edición. Madrid. McGraw Hill.

- Roldán, Alfonso (2009): "En cine y televisión es muy preocupante el tratamiento de la violencia contra las mujeres", entrevista a Inés París, presidenta de la Asociación de Mujeres Cineastas y de Medios Audiovisuales (CIMA). En Madrid sindical, no 131, pp. 24-25.

- Romero, Vicente (2001): “Cuando el cine no sabía hablar”. Capítulo III, [documental] Una moral de la época. Documental de la Filmoteca española y TVE.

- Saltzman, Joe. (2002): Frank Capra and the Image of the Journalist in American Film, [en línea] Disponible en: http://ijpc.org/uploads/files/capra_excerpts.pdf [23/02/2012].

- VV.AA. (2003): ARESTE. Arrinconando estereotipos en los medios de comunicación y la publicidad. Madrid: Dirección General de la Mujer, Consejería de Trabajo, Comunidad de Madrid. 